\title{
Maltese as a foreign language educators' acquisition of intercultural capabilities
}

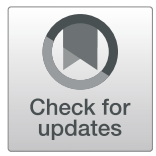

Jacqueline Żammit@

Correspondence: jacqueline. zammit@um.edu.mt

University of Malta, Msida, Malta

\section{SpringerOpen}

\begin{abstract}
This study sought to understand how teachers of Maltese as a foreign language (MFL) develop intercultural capabilities by exploring the importance of intercultural competence (IC) to MFL teachers, the characteristics of interculturally competent MFL educators, and the ways in which educators develop IC. The study adopted the interpretivist paradigm and a case study research design to collect qualitative data. Seventeen MFL teachers of adult learners were purposefully selected because they all taught MFL to non-native adults. These educators were interviewed, by answering the researcher's ten unstructured questions. A smartphone was used to record the interviewees. Findings regarding the perceptions of the teachers who were interviewed are as follows. Firstly, the participants stated that IC is important for MFL teachers because it helps them to embrace diversity, to help adult learners to learn the target language (i.e. Maltese) better, and to be sensitive and accommodative to learners from different backgrounds. Secondly, according to the participants, an interculturally capable person is one who knows their own culture and others' cultural aspects, respects and accepts other cultures. It was also found that teachers develop intercultural capabilities through learning at a school and by visiting other countries and being immersed in the cultures of those countries. The implications of the findings as supported by existing literature, are that $\mathrm{IC}$ is important for foreign language teachers and as a result, intercultural training, learning through interactions with others and visits to other countries are necessary to develop intercultural capabilities.
\end{abstract}

Keywords: Intercultural capabilities, Intercultural competence (IC), Teachers of Maltese as a foreign language (MFL), Intercultural communication competence, Multiculturalism, Cultural awareness

\section{Introduction}

In today's world, which is characterised by globalization, individuals are expected to be interculturally capable and sensitive in order to communicate effectively with people from different backgrounds and societies. One way in which individuals from different societies are able to interact and have meaningful cultural exchanges and a sense of belonging in the foreign country where they live is by learning and using that country's language.

(c) The Author(s). 2021 Open Access This article is licensed under a Creative Commons Attribution 4.0 International License, which permits use, sharing, adaptation, distribution and reproduction in any medium or format, as long as you give appropriate credit to the original author(s) and the source, provide a link to the Creative Commons licence, and indicate if changes were made. The images or other third party material in this article are included in the article's Creative Commons licence, unless indicated otherwise in a credit line to the material. If material is not included in the article's Creative Commons licence and your intended use is not permitted by statutory regulation or exceeds the permitted use, you will need to obtain permission directly from the copyright holder. To view a copy of this licence, visit http://creativecommons.org/licenses/by/4.0/. 
On the bilingual island of Malta, where Maltese and English have been its official languages since 1934 (Europeans and their Languages Report, 2012), foreign residents can communicate in English, but it is always an asset to know Maltese, especially if one lives in certain villages where Maltese is mostly spoken: this is the case in many villages around the island, such as Zabbar, Zejtun, Zebbug and Gozo. Educators who teach the new subject of Maltese as a foreign language (MFL) to non-native learners play an important role in teaching MFL. One important aspect of teaching individuals a new language is relating the language to the culture of that language and the culture of the learners. The relationship between language and culture is such that when one teaches a language, one also teaches the culture that is related to that language (Nhem, 2020).

It has also been argued that intercultural communication competence (ICC) is necessary in the twenty-first century (Zhang, 2017). Zhang (2017) also notes that the development of ICC is a phenomenon that will permeate all facets of activities involved in language teaching. In this vein, language teachers are expected to help learners develop ICC. To do this, foreign language (L2) teachers should, as argued by Zhang (2017), first be capable intercultural communicators who have great self-confidence and adequate experience. According to Mostafaei and Nosrati (2018), L2 teachers, as the critical players in the education of language, need to be interculturally competent and sensitive so as to be in a position to develop their learners' ICC and intercultural sensitivity.

It has also been acknowledged that integrating cultures in L2 teaching is necessary to enable L2 learners to grasp and improve their ICC in the globalised community (Thao \& Tai, 2017). However, Thao and Tai (2017) also point out that L2 educators in various contexts seem to ignore this important concept in their L2 teaching.

\section{The research problem and objective of the study}

IC is necessary for developing L2 and promoting inclusive schooling in the twenty-first century (Zhang, 2017). Moreover, teachers need to have intercultural competence (IC) to teach learners from different backgrounds effectively.

MFL is a new subject in Malta and it has began to be required since 2014 due to the influx of migrants in Malta. The need for a national policy for teaching MFL within the context of bilingualism and plurilingualism, which involves both children and adults, emerged in 2019 as a result of the significant advent of foreigners to Malta (The National Policy of the Teaching of Maltese as a Foreign Language within the Framework of Bilingualism and Plurilingualism, 2019). As the Directorate for Learning and Assessment Programmes states, MFL started being assessed at Primary, Middle and Secondary State schools in 2016. Most Maltese teachers are trained to teach Maltese as a first language (ML1), but they are not trained to teach MFL, and thus there is a lack of knowledge and research in MFL pedagogy (Camilleri Grima, 2015; Żammit, 2020) including IC. As a result, the current research contributes to knowledge in MFL and second language aquisition (SLA) as it sought to investigate how MFL teachers perceive the importance of IC and how they believe IC is developed.

This study specifically focused on providing an understanding of how a sample of 17 teachers developed intercultural capabilities in their teaching of MFL to adults. The objective of the study was to understand the perceptions of MFL teachers towards the importance of IC and to find out how educators develop IC. 


\section{Research questions}

The study sought to answer the following questions:

1. How important is IC according to MFL teachers?

2. How do teachers perceive the characteristics of an interculturally competent MFL educator?

3. What are the ways in which educators develop IC?

\section{Literature review}

\section{The IC of $\mathrm{L} 2$ teachers}

In L2 teaching, the theory of IC has been used for more than 20 years (Malau-Aduli, Ross, \& Adu, 2019). Due to the close connection between language and culture, L2 teachers need to be familiar with the cultural aspects of their own languages and those of their learners' languages (Deoksoon, 2020). The theory of IC has also centred on the need for L2 teachers to have IC (Deoksoon, 2020). There are many components of IC but the main three components are knowlege, skills and attitudes according to Deardorff (2006). IC can also be defined as being concerned with an individual's ability to shift their perspective to a culture other than their own (Arcagok \& Yllmaz, 2020).

According to Deardorff (2006), a key component of IC is attitude. The teacher should be curious, open and ready to suspend their disbeliefs about other cultures and their beliefs about their own culture. This implies a readiness to relativise one's own beliefs, values and behaviours, not to have the view that one's belief, value or behaviour is the only probably and scientifically correct one. It is important to be in a position to visualise how teachers may look from the perspective of another person who has a dissimilar set of beliefs, values and behaviours (Godfrey, 2020).

Another critical factor of IC is knowledge. Knowledge here refers not simply to awareness of a particular culture, but to knowledge about the functioning of social identities and social groups in one's own and others' cultures (Deardorff, 2006). L2 educators need to have knowledge of social groups and their practices and products in their own country and in their learners' countries. The educators also need to have knowledge about how other individuals see themselves, and awareness of other individuals (Deardorff, 2006).

The final component of IC is skills. L2 educators need the skills to make comparisons, to interpret and to relate (Deardorff, 2006). Therefore, they need to be able to interpret an occurrence or document from another culture, to explain it, and to relate it to another occurrence or document from their own culture (Bouchard, 2017). L2 educators also need to have the skill of interacting.

According to Bergami (2012), an individual who has developed ICC can establish relationships when interacting in L2; interacts efficiently, considering their opinions and needs; mediates interactions between persons of various backgrounds; and seeks to keep learning communicative competence. Additionally, Bergami (2012) notes that L2 teachers need to be adequately acquainted with L2 culture that is associated with the L2 that they teach. Teachers need to also be familiar with their own culture and have culture-general knowledge to assist them in explaining differences and similarities between cultures to their students. L2 teachers also need to understand both the 
stereotypes that learners have and how to handle the stereotypes in an L2 classroom. Teachers also need to know how to select relevant content, materials and learning tasks that enable learners to develop IC. Bergami (2012) suggests that teachers should employ teaching techniques that enhance their knowledge of social groups, ability to interpret documents or events from other cultures, ability to acquire new knowledge about a given culture, and critical cultural awareness.

L2 teachers also need to be favourably disposed towards the incorporation of IC teaching in their work and be ready to actually work towards attaining this objective (Bergami, 2012). Correspondingly, Dervin (2010) states that teachers need to exhibit interculturality in L2 teaching by developing ways of ensuring that the competence is developed.

\section{Ways in which educators develop IC}

Some of the ways through which educators develop IC are discussed below.

\section{Intercultural training}

Intercultural training is predominantly related to the training of adults who perform jobs that require them to interact with individuals from different cultures (Barrett, Byram, Lázár, Mompoint-Gaillard, \& Philippou, 2014). The training involves imparting knowledge to teachers about various aspects of IC and how to develop these aspects. For instance, teachers are trained on how to interact with ethnically diverse students and other attributes that make teachers interculturally competent (Barrett et al., 2014).

\section{Learning intercultural capabilities at school}

It has also been noted that the development of intercultural capabilities can take place through learning at school (Barrett et al., 2014). Specifically, it has been argued that interaction between native speakers of a language and L2 learners is at the core of enhancing both the learning of language and cultural understanding (Barrett et al., 2014). Additionally, as noted by Cloonan, Fox, Ohi, and Halse (2016, p. 11), "sharing is a critical part of intercultural exchange". In particular, when teachers share narratives about their experience of intercultural exchanges, they can develop their knowledge and consciousness of ethnic and cultural differences and can embrace these differences (Cloonan et al., 2016).

\section{Visits to other countries}

Some research has been done on how visits to other countries affect a person's IC. For example, Bergami (2012) found that L2 teachers who frequently travelled to foreign countries associated with the L2 that they taught felt that they could deal extensively with the traditions, daily life routines, education, youth culture, history, political systems and geography of those countries in a foreign language classroom. This however does not apply to the present study as the participants teaching MFL were actually Maltese living in Malta. 


\section{Teachers' perceptions of IC}

Studies on how teachers perceive IC have suggested the different meanings that teachers give to the phenomenon and its importance to teachers. The perceptions of different teachers towards IC as discussed in different studies are presented below under three categories.

\section{IC as an aspect of ethical orientation}

The ethical orientation perspective includes conceptions that relate to the ethically appropriate way of thinking, acting and being involved in situations that call for IC. This category includes values, interpersonal traits, principles and ways of action. For example, a study by Jokikokko (2005) noted that teachers, and other individuals who have worked in different environments other than schools, emphasised the importance of IC as a phenomenon that relates to "being aware of one's own values and objectives and being able to justify them to others" (p. 75). Jokikokko (2005) also identifies openness, being able to investigate one's own thinking, appreciation of diversity, patience, tolerance and critical thinking as some traits that a person develops when they have IC.

Similarly, according to Barrett et al. (2014), teachers consider IC to be important because it helps them develop attitudes of tolerance and openness towards other cultures and people.

\section{IC as an aspect of efficiency}

Efficiency is concerned with being able to cope with different situations, to act proficiently in different roles, and to shift smoothly from one responsibility to another (Jokikokko, 2005). It has been observed that IC enables teachers to have effective organizational skills, especially in situations where they are required to handle several issues simultaneously (Jokikokko, 2005). Along the same line, Haas (2019) points out that individuals with higher IC tend to be more involved in self-directed learning, experience better psychological wellbeing, and experience less stress.

In Jokikokko's (2005) study, some teachers were of the view that IC is important because it enables them to cope in situations like when dealing with a person whose language skills are poor, scenarios that require one to interpret body language and gestures, in cases where there is no common language. This denotes that IC enables teachers to be more professional and to handle stations that require them to apply intercultural skills in a better way.

\section{IC as a pedagogical aspect}

From a pedagogical perspective, IC is concerned with how teachers encounter learners within the school environment so as to promote the learning of students from diverse backgrounds (Jokikokko, 2005). Consequently, teachers view IC as a skill set that they can use to encourage, guide and interact with different learners (Jokikokko, 2005). Information about teachers' perceptions of IC is important because it provides an understanding about what teachers think about IC, which influences how teachers develop the required intercultural skills. This is part of the data that the current study aimed to collect. 


\section{Methodology}

\section{Selection of the research paradigm and its justification}

In this study, the researcher was interested in understanding how MFL teachers develop intercultural capabilities. The researcher was also interested in gaining knowledge regarding how MFL teachers understand intercultural capabilities, and the attributes of interculturally competent MFL teachers. Researchers take into consideration factors such as the research problem and people's own personal encounters when selecting a research paradigm (Creswell, 2014).

Given the complex and interconnected nature of the phenomena to be investigated, the researcher deemed it appropriate to use a qualitative (interpretivist) research paradigm. Interpretive researchers believe in adopting a detailed meaning of a phenomenon, exploring the understanding of the world in which they exist, and conducting research in a natural setting (Kivunja \& Kuyini, 2017; Rahi, 2017). They therefore collect data using real-life (qualitative) approaches like observation, interviews, reflective sessions, text messages and discourse (Kivunja \& Kuyini, 2017). The interpretivist paradigm allows researchers to obtain knowledge through a detailed description of the phenomenon in question (Lanka, Lanka, Rostron, \& Singh, 2020). The researcher chose the interpretivist paradigm to study the complex phenomenon of the intercultural skills that educators need to develop or already developed and to investigate the teachers' perceptions towards IC.

\section{Research design}

For an interpretive study, the research designs could include a naturalist methodology, a case study methodology, a grounded theory methodology, narrative inquiry, heuristic inquiry, phenomenology, action research, phenomenography and hermeneutics (Kivunja \& Kuyini, 2017). The case study methodology was used in the current study because the researcher wanted to get an in-depth understanding about how MFL teachers develop intercultural capabilities. The researcher was also interested in getting the participants' views regarding the importance of IC, how the teachers perceive the characteristics of an interculturally competent MFL educator, and how they think an educator develops IC. The case study design was selected because it enables the researcher to conduct an intensive and in-depth inquiry about a complex phenomenon within a real-world perspective (Yin, 2012). A case study can be an individual, a group of people, an institution, or any other phenomenon (Yin, 2012). For the current study, the case was a group of 17 teachers who teach MFL to adults.

\section{Population and sample}

A sample of 17 teachers was purposively selected from teachers who teach MFL to adults at evening classes or in private lessons (see the Additional file 1). The 17 teachers in this study have been teaching ML1 for more than ten years and thus, they did not receive any training of MFL including IC in their pedagogical training. A postgraduate training programme in teaching MFL started recently, in 2018. This postgraduate training was intended to teach Maltese teachers how to teach MFL and provide them with the necessary training to do so effectively. Maltese teachers need to 
be aware that teaching MFL requires a different pedagogy (including IC) than teaching ML1.

Purposeful or purposive sampling entails targeting participants who are perceived to have the most comprehensive knowledge about the phenomenon that is being investigated (Yilmaz, 2013). The researcher was of the opinion that the 17 teachers selected to participate in the study would be familiar with the topic, given their work of teaching MFL to adults from different cultures.

\section{Data collection tool and procedure}

Interviews were used as the data collection instrument in this study because the researcher wanted to get in-depth responses from the participants by talking to each one of them in person. As noted by Wolgemuth et al. (2014), interviews allow researchers to collect data about the participants' feelings and thoughts regarding a given phenomenon or experience that is being investigated. Thus, interviewing was considered as a suitable data collection method in this study.

Prior to conducting the study, the researcher sought ethical approval from the University of Malta's Faculty Research Ethics Committee (FREC). The researcher then, tested the ten interview questions with volunteers and peers, and conducted the interviews. The interviews were conducted at the participants' convenience and in their chosen comfortable location and time, in accordance with the guidance provided by McGrath, Palmgren, and Liljedahl (2018) on how to conduct interviews. With the participants' consent, the interviews were recorded using a smartphone.

In this research, the participants were asked ten unstructured questions during the interview. The questions were mainly purposed to identify the points of attitudes, views and opinions concerning IC. Each interview lasted roughly one hour, totalling seventeen hours of interviews. The following were the interview questions:

1. How long have you been teaching Maltese as a foreign language to adults?

2. What do you understand by 'IC'?

3. How do you teach Maltese as a foreign language to different cultural groups?

4. Do you consider IC important in teaching Maltese as a foreign language?

5. Do you use IC when teaching Maltese as a foreign language?

6. What do you think are the benefits of intercultural teaching and learning?

7. What are the characteristics of an intercultural educator?

8. How do educators develop IC?

9. How do you deal with culturally-sensitive topics in class?

10. Do you try to understand the different backgrounds of the learners you teach?

11. Could you kindly give me an example of a question that an intercultural competent teacher could ask?

\section{Data analysis}

The interview data were transcribed, coded, and analysed thematically to determine the emerging themes in relation to the research problem and research questions of this study. The coding was inductive, in that codes were developed from the data itself by identifying the inductive themes, coding them in a dataset, and then examining the 
meanings, context and implications of the themes. The themes were identified and coded by reading the data samples, creating codes to cover the sample and repeating the process for all the samples. In inductive coding, the researcher identifies the themes and patterns that emerge during the analysis, and these themes may be new and unexpected (Zamawe, 2015).

The information collected was analysed using the content evaluation approach, and the results were compiled into reports. The NVivo 10 programme validated the identified trends, allowing the researcher to analyse more of the qualitative findings, and discover deeper insights, while saving time and running more efficiently (Zamawe, 2015).

\section{Results and discussion}

Presentation of the results

Three main themes arose from the interpretation of the interview results, which contributed to the three objectives and the three research questions of this study, as one can find in the following table.

\section{Theme 1: teachers' perceptions of IC}

In this study, six teachers did not know the meaning of the term "IC" because they did not receive any training on teaching MFL in their pedagogical course. This could be due to the fact that the influx of immigrants in Malta is a current issue and the MFL pedagogical course began in 2018 (Żammit, 2020, 2021). Moreover the participants reported that they had not received intercultural training, whereas intercultural training is an important way of developing IC, so that teachers can amicably interact with ethnically diverse students (Barrett et al., 2014).

Eleven educators argued that IC is an important skill to profoundly support and validate the diverse students in their MFL classes. IC was characterized by seven participants as an essential ability for identifying and respecting students with different cultural affiliations; eight participants defined it as engaging and communicating with multicultural students in a significant, meaningful, and courteous manner; nine participants defined it as developing strong and fruitful relationships; seven participants described it as accepting diversity; eight participants defined it as being sensitive and accommodating to multicultural learners; and five participants defined it as engaging with others using socially and culturally appropriate features. For example, Participant 1 stated:

I believe that a teacher of Maltese as a foreign language should have IC to understand the adult students better, especially the aspects of different cultures that these students belong to. The teacher should also be sensitive and accommodating to learners from different cultures.

Similarly, Participant 4 noted:

I think having IC helps one understand aspects of other cultures such that it becomes easier to interact with learners and other teachers from different cultural backgrounds. It is important, for instance, to be able to use culturally relevant 
features when you are interacting with someone from a different culture. And it all begins with knowing how the people from a different culture greet each other, address others or express themselves, whether they use idioms in their language, and so forth. Also, it is important to know whether the other culture exhibits aggressiveness or politeness when communicating. As a teacher, when you know all these things about other cultures, you become more accommodative and not judgemental, and you also avoid stereotypes and prejudices when relating with others.

Participant 4's response echoes various aspects of the importance and relevance of IC discussed in the literature review. For instance, it was noted that individuals who have cultural awareness, which is one aspect of intercultural capabilities, are able to understand and empathise with others from different cultures in a non-judgemental way (Marczak, 2013). Such individuals are also tolerant and accommodative of others from different cultures (Marczak, 2013). More importantly, it was discussed that teachers who have intercultural capabilities are able to use culturally relevant features when communicating (Marczak, 2013), which is beneficial to MFL students.

\section{Theme 2: teachers' perceptions of the characteristics of an interculturally competent MFL educator}

Following the researcher's definition of the word "IC" as established by Deardorff (2006) to the six participants who did not know its meaning, another theme that emerged is that an interculturally competent MFL educator is cognisant of their own culture and others' cultures, respects and accepts other cultures, and acts appropriately when interacting with individuals from other cultures. Table 1 shows the frequency of the characteristics listed by participants for being an interculturally competent MFL educator.

For instance, Participant 3 claimed that:

A teacher who can be said to be interculturally capable is one who not only understands their culture but also has a good understanding of other cultures, and is able to act in ways that reflect the cultural conventions of the people with whom they are speaking. For instance, when I teach foreign adults who come from different backgrounds, I pay a lot of attention to what I say and also to what my students are saying, because I genuinely care for my students, especially for those minority groups in my class who always need support and adaptation. I remember that once I had a German student who was talking in English (not in Maltese) about the open relationship that she has with her boyfriend and offended other female students from different cultures. As a teacher, I felt that I was interculturally capable because I understood the German culture and also the Muslim and the Hindu cultures. I remember that I acted immediately by telling the women that we need to respect each other's cultures, and if we had been born in each other's country then we could have acted according to the way we were raised in that particular country. I remember that their argument ceased after what I told them.

Whereas Participant 3 looked at IC from a teacher's perspective who genuinely cares about their adult learners' different cultures and teaching them to respect each other, 
Table 1 The Study Main Themes (Continued)

\begin{tabular}{|c|c|c|c|}
\hline Theme & $\begin{array}{l}\text { Number of } \\
\text { Participants who } \\
\text { answered the } \\
\text { theme }\end{array}$ & The Theme's Factors & $\begin{array}{l}\text { Frequency } \\
\text { of mentions } \\
\text { of factors }\end{array}$ \\
\hline \multirow{12}{*}{$\begin{array}{l}\text { 3. The MFL educators' } \\
\text { development of IC }\end{array}$} & 17 & & \\
\hline & & $\begin{array}{l}\text { - Learning within the school } \\
\text { environment }\end{array}$ & 15 \\
\hline & & - Being tolerant of other cultures & 9 \\
\hline & & $\begin{array}{l}\text { - Interacting with learners on a day- } \\
\text { to-day basis }\end{array}$ & 14 \\
\hline & & $\begin{array}{l}\text { - Visiting other countries and } \\
\text { interacting with the local people }\end{array}$ & 15 \\
\hline & & - Embracing cultural diversity & 12 \\
\hline & & $\begin{array}{l}\text { - Being sensitive and } \\
\text { accommodative to learners from } \\
\text { different cultures }\end{array}$ & 11 \\
\hline & & $\begin{array}{l}\text { - Using socially and culturally } \\
\text { appropriate features during } \\
\text { communication }\end{array}$ & 9 \\
\hline & & $\begin{array}{l}\text { - Respecting and accepting other } \\
\text { cultures }\end{array}$ & 8 \\
\hline & & $\begin{array}{l}\text { - Understanding one's own culture } \\
\text { and those of others }\end{array}$ & 8 \\
\hline & & $\begin{array}{l}\text { - Observing and critically reflecting } \\
\text { one's own and their students' } \\
\text { behaviours }\end{array}$ & 11 \\
\hline & & $\begin{array}{l}\text { - Learning about various cultural } \\
\text { perspectives through constant } \\
\text { self-reflection }\end{array}$ & 11 \\
\hline
\end{tabular}

Participant 11 brought into perspective the notion that the teacher needs to respect and accept their students' culture as different from the teacher's. Participant 11 asserted that:

I think a teacher can be said to possess intercultural capabilities if the teacher respects and accepts the differences that exist between their own culture and the cultures of their students. You see, different cultures make us express ourselves differently, communicate differently, use non-verbal signs differently, interpret meanings differently, and do a whole lot of other things differently. If, as a teacher, I am able to acknowledge these differences and embrace and accommodate them when interacting with people from different cultures, especially my Maltese as a foreign language student, then I can be said to be interculturally capable.

Participant 11's response reflects what has been widely discussed in the literature concerning the interconnection between culture and language. One of the key points discussed is the need to respect the cultural values that pertain to different cultures. For example, Shemshadsara (2012), notes that "Because language is closely entwined with culture, language teachers entering a different culture must respect their cultural values" (p. 98). It is crucial for L2 teachers to be sensitive to the fact that learners, 
institutions, administrators, and others to not necessarily share their cultural paradigms (Shemshadsara, 2012).

Other participants emphasised that an interculturally competent teacher should be able to act appropriately at all times when interacting with people from other cultures. For example, Participant 8 noted that "one should always be accommodative and ready to help learners by understanding how their culture affects their ability to learn the new language". Similarly, Participant 16 pointed out that an interculturally capable teacher is an individual "who despite being different from their learners or those they interact with, is respectful at all times and goes the extra mile to ensure that any cultural differences that exist do not hinder effective interaction or communication."

Overall, the responses offered by all the participants, and in particular Participants 3, 8, 11 and 16 highlight elements of the triangular model of intercultural communicative competence suggested by Chen (2014). This model features three sets of capabilities that interculturally competent individuals should have. The capabilities are knowing one's own culture and others' cultural aspects, being able to respect and accept other cultures, and acting appropriately all the time when interacting with people from different cultures (Lum, 2018).

In the literature review, it was noted that teachers perceive IC as an aspect of ethical orientation, as an aspect of efficiency, and as a pedagogical aspect. IC as an ethical orientation denotes a person's awareness of their own values and objectives and ability to justify them to others (Jokikokko, 2005). Participants 3, 8, 11 and 16 highlighted their positive attitude towards IC by mentioning traits like openness, patience, tolerance and appreciation of diversity as some of the values that a teacher who has IC should have. Interestingly, the same values were highlighted in the study by Jokikokko (2005). The participants also highlighted some positive aspects associated with IC, such as one acting appropriately at all times when interacting with people from other cultures and being respectful to others, despite the cultural differences that exist. These two points underline the significance of IC as an aspect of efficiency (professionalism) and as a pedagogical aspect (related to the skills that teachers need to have) as discussed by Jokikokko (2005).

\section{Theme 3: the MFL educators' development of IC}

The participants discussed the various ways in which, from their own perspective, they have gained cultural capabilities, although they pointed out that they never received any intercultural training in their pedagogical courses. However, during their teaching experience, they learned how to interact with people of different cultures, and by visiting other countries or their general knowledge, they learned and became aware of new cultures. Some of the responses are highlighted below.

\section{Intercultural training}

All participants stated that their teacher training did not include any intercultural training sessions to prepare teachers to work in culturally diverse environments, since this multicultural situation was not existent previously, like when Participant 2 was being trained 20 years ago: 
Twenty years ago, our teacher training at university did not provide an intercultural training programme to prepare us, teachers, to work in culturally diverse environments. Multiculturalism in class was non-existent twenty years ago. I always used to teach in state schools and I always taught Maltese to Maltese students. In fact, I did not know what the words 'intercultural' or 'IC' meant and I asked you before answering your questions. Through reading, movies, travelling, getting to know new people from different countries, and even by hosting students from different countries, I learned a lot about other cultures, how different people express themselves, how they communicate and much more. I also learned how to be accommodative of other cultures, how to avoid prejudices and stereotypes, and how to embrace diversity. The result is that I have always been sensitive to people from other cultures. I do my best to understand them despite the differences that exist between us.

Six participants admitted that, similar to Participant 2, they did not know the definitions of 'intercultural' or ' $\mathrm{IC}$ ' and did not learn anything about interculture in their teacher training. This corresponds with Thapa (2019), who claimed that there could be a lack of intercultural sensitivity and intercultural communication in teacher training. Similarly, Participant 13 stated the following:

We lack intercultural training, but travelling and teaching foreigners has enabled me to be more sensitive, tolerant and accommodative when dealing with my learners who come from different cultures.

The responses above show that intercultural training, whether at the pre-service level or in teacher training, is important to enable teachers to develop intercultural capabilities. Bustamante, Skidmore, Nelson, and Jones (2016) discussed the importance of integrating intercultural training in teacher training programmes to make teachers aware of diversity. Similarly, it has been noted that intercultural training helps teachers to gain knowledge about various aspects of IC and to develop intercultural capabilities (Barrett et al., 2014).

\section{Learning while interacting with others at school}

Fifteen participants mentioned that they learned IC while interacting with their students as a way of developing their intercultural capabilities expressed different views regarding how this happened. For example, Participant 13 noted that:

I have developed intercultural skills through my interactions with learners who are from different cultures. One case that I remember very well was when I came across three Somali adults who were interested in learning Maltese as a foreign language so that they could obtain their long-term residence status in Malta. They were making every effort to pronounce well in Maltese, and I took it upon myself to help them by learning some aspects of the Somali culture and teaching some aspects of the Maltese culture. While doing so, I realised that I was learning some aspects of their culture but, most importantly, I was learning 
to tolerate their culture and not to show them that my culture is better, for instance.

Similarly, Participant 10 claimed that:

My daily interactions with learners from different cultures enable me to learn about multiculturalism and the need to embrace diversity. I remember asking my students to talk about their country's role models and I became aware, and then made my students aware, that people of different ethnicities, gender, etc. can have different impacts on the world, and thus everyone needs to be respected.

The views expressed by all participants reflect what researchers have described about learning intercultural capabilities at school. For example, Barrett et al. (2014) suggested that the development of intercultural capabilities can also take place through learning within the school environment. As native speakers of a language interact with learners of the language, they share various aspects of their experiences, language and culture, and these intercultural exchanges lead to a developing consciousness of ethnic and cultural differences (Cloonan et al., 2016). For instance, Participant 13 agreed with 9 participants who claimed that interacting with learners from different cultures enabled the educator to develop intercultural capabilities by being tolerant of other cultures, and with 5 participants who mentioned that an educator should not show the learners that the teacher's culture was better. Similarly, Participant 10's response was one of the 14 participants who explained that interacting with learners on a day-to-day basis enabled the teacher to learn about multiculturalism and why it is necessary to embrace diversity. Through such interactions, L2 teachers are able to develop a sense of consciousness regarding ethnic and cultural differences, in the same way as discussed by Cloonan et al. (2016).

\section{Visiting other countries}

Fifteen participants indicated that visiting other countries enabled them to learn about the language and cultural aspects of these countries, which was critical in their work as MFL teachers. Participant 6 stated the following:

During evening classes, I meet many nurses who come from rural areas of India. To learn how to interact well with these students, I visited India and stayed in the country for three months during my summer vacation. During this period, I interacted with many individuals in India, learned about their culture and cuisine, how they greet and interact with people of different ages, and so forth. My stay in India was worth it because it helped me learn a lot about how to teach and communicate with my Indian students.

Participant 8 also talked about the importance of visiting other countries to learn different cultures, noting that: 
I have visited many countries and interacted with people in these countries to learn about their languages and culture. These experiences have enhanced my intercultural capabilities.

Similarly, Participant 14 pointed out the following:

Visiting various countries and interacting with the people has enabled me to learn about different languages and cultures and how to interact with students from diverse backgrounds.

The responses above suggest that when MFL teachers visit different countries, they can obtain the cultural knowledge that they need to apply when dealing with learners from the countries they have visited. Such knowledge is related to aspects like language, communication, food and others. In the literature, various authors have discussed visits by L2 teachers to the countries associated with the language that they teach to help them improve their IC and enhance their intercultural understanding (Barrett et al., 2014). Bergami (2012) illustrates this point by noting that L2 teachers who frequently visited foreign countries linked with the L2 they teach were of the view that such visits enabled them to understand some aspects about those countries. These aspects include traditions, youth culture, daily life routines, education, the history, political systems and geography of those countries (Bergami, 2012). Based on Bergami's (2012) study, these 15 teachers indicated that they could apply the knowledge gained during such visits in their L2 teaching.

It is also important to point out that these 15 participants stayed for some time (a minimum of 3 months) in the countries that they visited and interacted with the local people there. This is important for cultural immersion. In the literature, it has been noted that repeated visits to a country or staying in the visited country for at least 3 months, coupled with interacting with the local people in that country, enhances a person's intercultural sensitivity or IC (He, Lundgren, \& Pynes, 2017).

The implications of the results are as follows. To start with, it was found that IC helped 12 teachers to embrace cultural diversity, 11 teachers to be sensitive and accommodative to learners from different cultures, and 9 teachers to use socially and culturally appropriate features during communication. According to Deardorff (2006), L2 teachers need to have certain skills, knowledge and attitudes that depict their IC. For example, teachers are expected to use language in a socially and culturally fitting way when communicating, and to understand their own culture and the aspects of other cultures and languages (Makhmudov, 2020). Teachers also need to know how to select content, materials and learning tasks that are relevant and which enable learners to develop IC (Bergami, 2012).

The second issue pertains to the finding that according to 8 participants, an interculturally competent MFL educator is one who not only understands their own culture and those of others but also respects and accepts other cultures and acts appropriately during interactions with people from other cultures. Previous studies (e.g. Bal \& Savas, 2020; Sarwan \& Wahab, 2017), have also established that L2 teachers who are interculturally competent have attributes like respecting and valuing other cultures, being 
accommodative and open towards people from other cultures, and treating people from different backgrounds fairly.

The third issue relates to the finding that the participants felt that they have developed IC through interactions with others at school and visits to other countries. Through the interactions and exchanges, teachers can develop their knowledge and consciousness of cultural differences and be able to embrace these differences (Cloonan et al., 2016).

Consequently, according to eleven participants, developing IC involves observing and critically reflecting their own and their students' behaviours. Although there are several models of IC, fundamental components comprise three basic elements: attitudes, knowledge and skills (Deardorff, 2006) and Table 2 shows the participants' examples of these basic elements.

We often tend to react to new individuals or circumstances with subjective judgments, imposing our opinions into what we believe we see, or hear or feel (Yunlong, 2014). In fact, eleven participants agreed that MFL educators should learn about various cultural perspectives through constant self-reflection to improve their intercultural knowledge and successful culturally sensitive teaching.

\section{Limitations}

The study had some limitations. First is that although purposeful sampling involves focusing on a small number of people or a unique case with comprehensive information about the phenomenon being investigated, the small sample size limits the possibility of generalising the findings to other settings or situations (Yilmaz, 2013). Hence, the findings of the current study may not be generalizable although they can easily be applied to any L2 teaching and learning.

The second limitation concerns the nature of the sample. According to Allen (2017), purposeful sampling may be affected by an error in the researcher's judgement, leading to a biased or flawed sample. It is notable that MFL educators might have been quite subjective when giving their opinion concerning intercultural capabilities. Moreover, some of the teacher's narratives of their experience of intercultural capabilities deviated from the subject that the researcher was exploring, and thus actually had nothing to do

Table 2 Examples of the Fundamental Components of IC

\begin{tabular}{ll}
\hline $\begin{array}{l}\text { Components } \\
\text { of IC }\end{array}$ & $\begin{array}{l}\text { Reflective Questions that interculturally competent teachers might pose, according to } \\
\text { the participants }\end{array}$ \\
\hline Attitudes & $\begin{array}{l}\text { Participant 10: "Am I open, interested, and willing to learn from my students?" } \\
\text { Participant 4: "Do I have prejudices about my students?" } \\
\text { Participant 7: "What do I do if I misunderstand what my students are saying?" }\end{array}$ \\
Knowledge & Participant 13: "Which principles, habits, and ideals shape my mindset, behaviour, and \\
& conversation, and also those of my students?" \\
& Participant 16: "Is it possible for me to recognise my own cultural behaviour and understand \\
& Why I think and behave the way I do?" \\
& Participant 1: "Is it clear to me how my students want to be handled?" \\
& Participant 5: "How do I adjust my perspective so that I define my students' behaviours \\
& before judging them?" \\
& Participant 2: "Do I react in a culturally sensitive way?" \\
& Participant 17: "How far do I actually pay attention to my students?"
\end{tabular}


with intercultural capabilities. Six educators even had no idea what the term "IC" meant.

\section{Conclusion}

This study's aims were to to explore the educators' perceptions of IC, to identify the characteristics of an interculturally competent MFL teacher, and to investigate how MFL teachers develop intercultural capabilities according to the participants. Six participants reported that they did not know the meaning of "IC" because MFL is a new subject and they were not trained to teach MFL including IC. Therefore, this study contributed to MFL knowldge and also to L2 knowledge concerning IC. This study concludes that it is necessary for L2 teachers to develop intercultural capabilities. This will enable teachers to embrace and accommodate other cultures and to communicate in a socially and culturally appropriate manner when interacting with individuals from other cultures.

The participants listed several characteristics that an interculturally competent MFL educator ought to have, like empathising with other's emotions and wishes; respecting other people's communication habits; recognising, respecting and embracing one's own culture and other cultures; learning an L2; keeping an open mind and being curious about what is unfamiliar; establishing new understanding links among various social classes; feeling confident in one's own goals, talents, flaws, and mental well-being; improving one's own listening skills by writing and speaking clearly; and investigating other cultures in considerable depth than a typical Facebook post.

Another finding is related to the ways which educators develop intercultural capabilities. The participants felt that they have developed IC through interactions with others at school and by visiting other countries and interacting with people in these countries. This finding implies that learning institutions need to encourage intercultural learning by promoting diversity and interactions between and among MFL teachers and students.

The participants also proposed intriguing self-reflective questions that highlight three fundamental components of IC, including attitudes, knowledge, and skills. This implies that developing IC also requires an educator's mindset change; which is a continuous and highly satisfying process. This study concludes that an MFL teacher's truthful and transparent interaction is important to educating diverse adult students who need and deserve to be accepted, respected, supported and understood.

Abbreviations

IC: Intercultural competence; ICC: Intercultural communication competence; L2: Second/foreign language; MFL: Maltese as a foreign language

\section{Supplementary Information}

The online version contains supplementary material available at https://doi.org/10.1186/s40862-021-00116-3.

Additional file 1. The MFL Learners of the 17 Teachers. 


\section{Funding}

The author received no financial support for the research and authorship. The University of Malta paid for the publication of this article through the Academic Work Resources Fund.

\section{Availability of data and materials}

Please contact the author for data requests.

\section{Declaration}

\section{Competing interests}

The author declares that she has no competing interests.

Received: 20 March 2021 Accepted: 4 June 2021

Published online: 16 June 2021

\section{References}

Allen, M. (2017). Survey: Sampling issues. The SAGE Encyclopedia of Communication Research Methods. https://methods.sa gepub.com/reference/the-sage-encyclopedia-of-communication-research-methods/i14379.xml

Arcagok, S., \& Yılmaz, C. (2020). Intercultural sensitivities: A mixed methods study with pre-service EFL teachers in Turkey. Issues in Educational Research, 30(1), 1-18.

Bal, N. G., \& Savas, P. (2020). IC in the eyes of state school English language teachers in Turkey. Journal of Language and Education, 6(2), 56-75.

Barrett, M., Byram, M., Lázár, I., Mompoint-Gaillard, P., \& Philippou, S. (2014). Developing IC through education. Council of Europe Publishing: Pestalozzi Series, No. 3.

Bergami, R. (2012). Enhancing intercultural competence through international study Tours. International Journal of the Humanities, 9(11), 41-57.

Bouchard, J. (2017). Ideology, agency, and intercultural communicative competence: A stratified look into EFL education in Japan. Springer Nature Singapore Private Ltd. https://doi.org/10.1007/978-981-10-3926-3.

Bustamante, R. M., Skidmore, S. T., Nelson, J. A., \& Jones, B. E. (2016). Evaluation of a cultural competence assessment for preservice teachers. The Teacher Educator, 51(4), 297-313. https://doi.org/10.1080/08878730.2016.1186767.

Camilleri Grima, A. (2015). Exploring the acquisition of Maltese by adult foreign learners: A focus on verbal tense and aspect. Malta Review of Educational Research, 9(1), 57-77.

Chen, G. M. (2014). Intercultural communication competence: Summary of 30-year research and directions for future study. In X.-d. Dai, \& G. M. Chen (Eds.), Intercultural communication competence: Conceptualization and its development in cultural contexts and interactions, (pp. 4-29). Cambridge Scholars.

Cloonan, A., Fox, B., Ohi, S., \& Halse, C. (2016). An analysis of the use of autobiographical narrative for teachers' intercultural learning. Teaching Education, 1-14, 131-144.

Creswell, J. W. (2014). Research design: Qualitative, quantitative and mixed methods approaches, (4th ed., ). SAGE publications.

Deardorff, D. K. (2006). The identification and assessment of intercultural competence as a student outcome of internationalization at institutions of higher education in the United States. Journal of Studies in International Education, $10(3), 241-266$

Deoksoon, K. (2020). Learning language, Learning Culture: Teaching Language to the Whole Student. SAGE Journals, 3(3), 519-541 https://journals.sagepub.com/doi/abs/10.1177/2096531120936693\#.

Dervin, F. (2010). Assessing IC in language learning and teaching: A critical review of current efforts in higher education. New Approaches to Assessment in Higher Education, 5, 155-172.

Europeans and their Languages Report (2012). Special Eurobarometer 386. European Commission https://ec.europa.eu/ commfrontoffice/publicopinion/archives/ebs/ebs_386_en.pdf.

Godfrey, T. (2020). How do teachers develop?. https://tomgodfrey.wordpress.com/2020/09/15/how-do-teachers-develop/

Haas, B. W. (2019). Enhancing the IC of college students: A consideration of applied teaching techniques. International Journal of Multicultural Education., 21(2), 81-96.

He, Y., Lundgren, K., \& Pynes, P. (2017). Impact of short-term study abroad program: In-service teachers' development of IC and pedagogical beliefs. Teaching and Teacher Education, 66, 147-157. https://doi.org/10.1016/j.tate.2017.04.012.

Jokikokko, K. (2005). Interculturally trained Finnish teachers' conceptions of diversity and IC. Intercultural Education, 16(1), 6983. https://doi.org/10.1080/14636310500061898.

Kivunja, C., \& Kuyini, A. B. (2017). Understanding and applying research paradigms in educational contexts. International Journal of Higher Education, 6(5), 26-41. https://doi.org/10.5430/ijhe.v6n5p26.

Lanka, E., Lanka, S., Rostron, A., \& Singh, P. (2020). Why we need qualitative research in management studies. Journal of Contemporary Administration, 25(2), 1-7.

Lum, C. M. K. (2018). Developing IC in the language classroom. In J. I. Liontas (Ed.), The TESOL encyclopedia of English language teaching, (pp. 1-6). Wiley. https://doi.org/10.1002/9781118784235.eelt0282.

Makhmudov, K. (2020). Ways of forming intercultural communication in foreign language teaching. "Science and Education" Scientific Journal, 1(4), 84-89.

Malau-Aduli, B. S., Ross, S., \& Adu, M. D. (2019). Perceptions of IC and institutional intercultural inclusiveness among first year medical students: A 4-year study. BMC Medical Education, 19(1), 346. https://doi.org/10.1186/s12909-019-1780-y.

Marczak, M. (2013). Communication and information technology in (intercultural) language teaching. Cambridge Scholars Publishing.

McGrath, C., Palmgren, P. J., \& Liljedahl, M. (2018). Twelve tips for conducting qualitative research interviews. Medical Teacher, 41(9), 1002-1006 https://www.tandfonline.com/doi/full/10.1080/0142159X.2018.1497149.

Mostafaei, M., \& Nosrati, A. F. (2018). Research into EFL teachers' intercultural communicative competence and intercultural sensitivity. Journal of Intercultural Communication Research, 47(2), 73-86. https://doi.org/10.1080/17475759.2018.1424020. 
Nhem, D. (2020). Culture and ELT: Cambodian teachers' perception and practice of textbook adaptation to realize intercultural awareness. Journal of English Language Teaching, 9(1), 65-74.

Rahi, S. (2017). Research design and methods: A systematic review of research paradigms, sampling issues and instruments development. International Journal of Economics \& Management Sciences, 6(2), 1-5.

Sarwari, A. Q., \& Wahab, M. N. A. (2017). Study of the relationship between intercultural sensitivity and intercultural communication competence among international postgraduate students: A case study at university Malaysia Pahang Cogent Social Sciences, 3(1), 1-11 https:/www.tandfonline.com/doi/full/10.1080/23311886.2017.1310479.

Shemshadsara, Z. G. (2012). Developing cultural awareness in foreign language teaching. English Lanquage Teaching, 5(3), 95-99.

Thao, T. Q., \& Tai, P. T. (2017). The importance of intercultural communicative competence in English language teaching and learning. In Paper presented at the innovation and creativity in teaching and learning foreign languages conference, may 2017 at HCMC Open University, Ho Chi Minh City.

Thapa, S. (2019). Assessing IC in teacher education: A missing link. In H. Westerlund, S. Karlsen, \& H. Partti (Eds.), Visions for Intercultural Music Teacher Education. Landscapes: The Arts, Aesthetics, and Education, 26. Springer.

The National Policy of the Teaching of Maltese as a Foreign Language within the Framework of Bilingualism and Plurilingualism. (2019). https://meae.gov.mt/en/Public_Consultations/MEDE/Pages/Consultations/TheNationa IPolicyoftheTeachingofMalteseasaForeignLanguagewithintheFrameworkofBilingualismandPlurilingual.aspx

Wolgemuth, J. R., Erdil-Moody, Z., Opsal, T., Cross, J. E., Kaanta, T., Dickmann, E. M., \& Colomer, S. (2014). Participants' experiences of the qualitative interview: Considering the importance of research paradigms. Qualitative Research, 15(3), 351-372 https://journals.sagepub.com/doi/abs/10.1177/1468794114524222.

Yilmaz, K. (2013). Comparison of quantitative and qualitative research traditions: Epistemological, theoretical, and methodological differences. European Journal of Education, 48(2), 311-325. https://doi.org/10.1111/ejed.12014

Yin, R. K. (2012). Applications of case study research, (3rd ed., ). SAGE Publications.

Yunlong, H. (2014). Constructing intercultural communicative competence framework for English learners. Cross-Cultural Communication, 10(1), 97-101.

Zamawe, F. C. (2015). The implication of using NVivo software in qualitative data analysis: Evidence-based reflections. Malawi Medical Journal, 27(1), 13-15. https://doi.org/10.4314/mmj.v27i1.4.

Żammit, J. (2020). The benefits and challenges of distance education in teaching Maltese as second language to adults. Malta Review of Educational Research, 14(2), 273-299.

Żammit, J. (2021). Maltese educators' perceptions of democracy, equality and justice in multicultural education. IAFOR Journal of Education: Inclusive Education, 9(1), 153-171. https://doi.org/10.22492/ije.9.1.09.

Zhang, Y. (2017). A study on ESL teachers' intercultural communication competence. English Language Teaching, 10(11), 229235. https://doi.org/10.5539/elt.v10n11p229.

\section{Publisher's Note}

Springer Nature remains neutral with regard to jurisdictional claims in published maps and institutional affiliations.

\section{Submit your manuscript to a SpringerOpen ${ }^{0}$ journal and benefit from:}

- Convenient online submission

- Rigorous peer review

- Open access: articles freely available online

- High visibility within the field

- Retaining the copyright to your article

Submit your next manuscript at $\boldsymbol{\nabla}$ springeropen.com 